\section{Effect of the Insect Growth Regulator Novaluron (Pedestal) on Silverleaf Whitefly Reproduction}

\author{
Raymond A. Cloyd, \\ Stephen R. Keith ${ }^{1}$, and \\ Cindy L. Galle ${ }^{1}$
}

ADDITIONAL INDEX WORDs. silverleaf whitefly, novaluron, insect growth regulator, greenhouse, floriculture, egg viability

SUMMARY. Insect growth regulators, which are primarily used to kill the larval stages of certain insect groups, have indirect effects on the adult stage of whiteflies. In this study, we assessed the effect of the insect growth regulator novaluron (Pedestal) on the reproduction of silverleaf whitefly (Bemisia argentifolii). Two experiments were conducted by exposing adult female silverleaf whiteflies to the low [0.47 $\left.\mathrm{mL} \cdot \mathrm{L}^{-1}(6 \mathrm{fl} \mathrm{oz} / 100 \mathrm{gal})\right]$ and high $\left[0.63 \mathrm{~mL}^{-1}(8 \mathrm{fl} \mathrm{oz} / 100 \mathrm{gal})\right]$ labelrecommended rates of novaluron. There was also an untreated control. Infested plants [mist flower (Eupatorium coelenstinum) and transvaal daisy (Gerbera jamesonii) for Expt. 1 and Expt. 2, respectively] containing adult female silverleaf whiteflies were sprayed with novaluron using a carbon dioxide $\left(\mathrm{CO}_{2}\right)$ backpack sprayer. Plants were immediately placed into cages covered with antivirus insect screening. After 24 hours, six adult female silverleaf whiteflies were aspirated from the treated plants, and immobilized with $\mathrm{CO}_{2}$ before being placed onto untreated plants [transvaal daisy for Expt. 1, and rose-of-china (Hibiscus rosa-sinensis) for Expt. 2]. Three munger cells containing two adult female silverleaf whiteflies per cell were attached to leaves of each of the untreated plants. The number of live and dead eggs, and live nymphs per plant was assessed 4 and 8 days after treatment (DAT). In Expt. 1, the low rate of novaluron significantly reduced

Department of Natural Resources and Environmental Sciences, University of Illinois, Urbana, IL 61801.

${ }^{1}$ AllTech Research and Development, Sparta, IL 62286. egg viability compared to the untreated control based on live nymphal counts 8 DAT. In Expt. 2, both rates of novaluron significantly reduced egg viability compared to the untreated control, based on live nymphal counts and number of dead eggs 8 DAT. The results from this study indicate that novaluron negatively affected female silverleaf whitefly reproduction by reducing egg viability, which may decrease the number of silverleaf whiteflies produced during a cropping cycle. This is an important long-term pest management strategy that may reduce the number of insecticide applications and decrease labor costs.

S ilverleaf whitefly is a major insect pest on ornamental plants grown in greenhouses, and is primarily managed using systemic insecticides such as imidacloprid (Marathon; Olympic Horticultural Products, Bradenton, Fla.) and insect growth regulators (Lindquist, 1998). Insect growth regulators may be placed into two general categories: juvenile hormone mimics or analogs, and chitin synthesis inhibitors (Olkowski et al., 1991; Ware, 2000). Juvenile hormone mimics interfere with insect development and prevent insects from completing their lifecycle. As a result, insects either fail to reach adulthood because they die as immatures, or they mature into sterile adult females (Medina et al., 2003). Chitin synthesis inhibitors influence the insect's ability to molt by inhibiting the formation of chitin, which is an essential component of an insect's exoskeleton. Insects die while molting from one stadium to the next (Olkowski et al., 1991; Ware, 2000).

Although insect growth regulators generally are only effective on the larval or nymphal stages of insects (Ware, 2000), studies have shown that insect growth regulators can indirectly affect the adult stages by reducing reproductive capacity or egg viability (Nassar et al., 1972). Egg viability is one way to assess reproduction, and may be defined as those eggs that hatch into live nymphs or larvae. Several studies have evaluated the effects of insect growth regulators, such as pyriproxyfen (Ishaaya and Horowitz, 1995) and buprofezin ( Asai et al., 1985; Yasui et al., 1987), on the viability of whitefly eggs. These studies have found that when adult female whiteflies are directly sprayed with insect growth regulators, there is a reduction in egg viability or eggs fail to hatch. This effect is greatest on young adult female whiteflies that are treated (Asia et al., 1985) coinciding with the development of the oocyte, which may effect cuticle formation of maturing eggs (Asai et al., 1985).

The insect growth regulator novaluron (Pedestal; Crompton Uniroyal Chemical, Middlebury, Conn.), which is a chitin synthesis inhibitor, has activity on the eggs and larvae of sweet potato whitefly (Bemisia tabaci) (Ishaaya et al., 1996). However, minimal information is available on the effect of novaluron on silverleaf whitefly, which is the primary whitefly species in greenhouses, particularly on poinsettia (Euphorbia pulcherrima) (Lindquist, 1990). As a result, the objective of this study was to determine if novaluron affects silverleaf whitefly reproduction by inhibiting egg viability.

\section{Materials and methods}

EXPT. 1. The following procedure was used to infest plants with silverleaf whitefly. Silverleaf whitefly populations were maintained on poinsettia and transvaal daisy plants enclosed in an infestation chamber. The silverleaf whiteflies were originally obtained from Bohn Nursery (Collinsville, Ill.) and Keith Nursery (Marissa, Ill.), and were identified as silverleaf whitefly based on morphological characteristics (Dreistadt, 2001). The enclosed chamber was $2 \mathrm{~m}$ wide $\times 5 \mathrm{~m}$ long $(6.6 \times 16.4$ $\mathrm{ft}$ ), with an A-frame roofline measuring $142 \mathrm{~cm}$ ( 55.9 inches) at point with the sides $91 \mathrm{~cm}$ (35.8 inches) high. There was a single wire-mesh bench inside the chamber. The bench height from the floor was $91 \mathrm{~cm}$. The roof and ends were covered with clear $8-\mathrm{mm}(0.31$ inch) corrugated polycarbonate, and the sides and bottom were covered with antivirus insect screening $50 \times$ $24[0.2 \times 0.8 \mathrm{~mm}(0.008 \times 0.031$ inch); Greentek, Edgerton, Wis.]. The sides were rolled up and secured with Velcro when closed. Poinsettia and transvaal daisy plants, obtained from H.M. Buckley and Sons (Springfield, Ill.) and Earl J. Small Growers (Pinellas Park, Fla.) were rotated and replaced with healthy plants approximately every 2 weeks to maintain the silverleaf whitefly colony.

Mist flower plants to be infested with silverleaf whiteflies were approximately $25 \mathrm{~cm}$ (9.8 inches) high when they were transplanted into $1.8-\mathrm{L}$ 
(0.48 gal) containers in a growing medium (MetroMix 700; Scotts Co., Marysville, Ohio) containing $50 \%$ to $60 \%$ composted pine bark, $20 \%$ to $30 \%$ Canadian sphagnum peat moss, $5 \%$ to $15 \%$ medium grade horticultural vermiculite, and $5 \%$ to $15 \%$ horticultural perlite. The plants were top-dressed after planting with $5 \mathrm{~g}(0.2 \mathrm{oz})$ of 14N-6.1P-11.6K Osmocote (Scotts Co.) granular fertilizer. None of the plants used in this experiment had been previously treated with a systemic insecticide or insect growth regulator. Three days after transplanting, 21 mist flower plants were placed into the infestation chamber in order to become infested with silverleaf whiteflies. Additionally, 21 separate transvaal daisy plants grown under similar conditions were left un-infested to serve as hosts for the treated female silverleaf whiteflies (described below). Based on daily observations of silverleaf whitefly adults emerging from pupae in the infestation chamber, we allowed the mist flower plants to remain in the chamber for 7 to $10 \mathrm{~d}$ to obtain adult silverleaf whiteflies that were similar in age. Once the plants were infested with a moderate silverleaf whitefly population (range: 25 to 50 per plant), each plant was removed from the chamber and sprayed with one of three treatments. The treatments were the low and high label-recommended rates of novaluron (Pedestal; Crompton Uniroyal Chemical) at 0.47 and $0.63 \mathrm{~mL} \cdot \mathrm{L}^{-1}$, and an untreated control.

Both the upper and lower leaf surfaces of each plant were thoroughly sprayed with a fine mist to ensure that all the silverleaf whiteflies present on each plant had been in contact with the spray solution. Applications were made using a $\mathrm{CO}_{2}$ backpack sprayer [275.8 kPa (40 psi); flat fan nozzle8002; $\left.378.5 \mathrm{~L} \cdot \mathrm{min}^{-1}(100 \mathrm{gal} / \mathrm{min})\right]$. After the appropriate treatments had been made, each replicate (plant) was individually placed into a vegetable cage $[30 \mathrm{~cm}$ diameter base $\times 76 \mathrm{~cm}$ height $(11.8 \times 29.9$ inches, respectively)] covered with antivirus insect screening $50 \times 24$ (Greentek)

Twenty-four hours after treatments had been made, six adult female silverleaf whiteflies were aspirated from each treated replicate plant using a battery-operated vacuum (Hausherr's Machine Works, Toms River, N.J.). The vacuum was fitted with a $5-\mathrm{cm}$ (2.0 inches) vial, $3 \mathrm{~cm}$ (1.2 inches) in diameter, with a mesh screen on the end inserted into the vacuum component, and a $15-\mathrm{cm}^{-}$(5.9 inches) long tube with a $0.9-\mathrm{cm}(0.35$ inches $)$ opening that was connected to a rubber fitting on the opposite end. Silverleaf whiteflies were immobilized by exposing them to $75 \% \mathrm{CO}_{2}$ for 4 s. Three munger cells (Robb, 1989) containing two adult female silverleaf whiteflies per cell were attached to the leaves of the separate group of 21 untreated transvaal daisy plants. The munger cells were attached to the top of the leaf and secured at each of four corners by twist ties. All test plants were held in a laboratory set at $25^{\circ} \mathrm{C}$ $\left( \pm 4{ }^{\circ} \mathrm{C}\right)\left[77.0^{\circ} \mathrm{F}\left( \pm 7.2^{\circ} \mathrm{F}\right)\right], 50 \%$ to $60 \%$ relative humidity $(\mathrm{RH})$, with 16 h light $/ 8$ h dark photoperiod. Plants were irrigated as needed with a handheld sprinkler.

The experiment was set up in a completely randomized design with three treatments and seven replicate untreated plants per treatment with three munger cells per plant. There were a total of 21 untreated plants with six adult female silverleaf whiteflies per plant. The number of live eggs laid by the adult female silverleaf whiteflies and number of live nymphs per munger cell was assessed 4 and 8 DAT using a dissecting microscope. Hatched eggs were not counted. Silverleaf whitefly eggs were determined to be alive based on color and appearance. Live eggs were golden-yellow in color, and were not shriveled or shrunken. The edge of the munger cell was slightly raised on one side from the upper leaf surface to prevent the two silverleaf whiteflies from escaping during the 4 DAT reading. Adult female silverleaf whiteflies were confined in the munger cells for $8 \mathrm{~d}$.

All data were analyzed using SAS Systems for Windows, version 8.0, in a completely randomized design using a one-way analysis of variance (ANOVA) (SAS Institute, 2002). Treatment means for the number of live eggs laid by adult female silverleaf whiteflies, based on pooling the data from all three munger cells, provided the number of live eggs and live nymphs per plant. This data was used to determine egg viability. All significant treatment means were separated using a Fisher's protected least significant difference (LSD) test at $P \leq 0.05$. Egg viability was measured by counting the number of live nymphs that were present 4 and 8 DAT following placement on untreated plants (transvaal daisy). This procedure of assessing egg viability based on nymphal counts has been used in previous studies (Asai et al., 1985).

Expt. 2. This experiment was conducted in the same manner as Expt. 1 except that the plants initially infested with silverleaf whitefly were transvaal daisy, and the untreated plants on which adult female silverleaf whiteflies were placed was rose-of-china. Similar to Expt. 1, none of the plants used in this experiment had been previously treated with a systemic insecticide or insect growth regulator. Different plant species were used in this experiment due to availability of plant material.

All data were analyzed in a completely randomized design using a oneway ANOVA (SAS Institute, 2002). Treatment means for the number of live eggs laid by the adult female silverleaf whiteflies, based on pooling the data from all three munger cells, provided the number of live eggs and live nymphs per plant. This was used to determine egg viability. All significant treatment means were separated using a Fisher's protected LSD test at $P \leq 0.05$. As with Expt. 1, we determined egg viability by counting the number of live nymphs that were present 4 and $8 \mathrm{~d}$ following placement on rose-of-china plants. In addition, the number of dead eggs was assessed. Silverleaf whitefly eggs that were considered dead had brown edges, and were shrunken and shriveled in appearance.

\section{Results}

ExPT. 1. There were no significant differences among the treatments for the number of live silverleaf whitefly eggs $(F=0.47 ; \mathrm{df}=2,20 ; P=0.63)$ or the number of silverleaf whitefly nymphs $(F=0.31 ; \mathrm{df}=2,20 ; P=0.73)$ $4 \mathrm{~d}$ after being placed onto untreated plants (Table 1 ). After 8 d on untreated plants, there was no significant difference among the treatments for the number of live eggs $(F=2.63$; df $=$ $2,20 ; P=0.11)$; however, there was a significant difference in the number of live nymphs $(F=4.40 ; \mathrm{df}=2,20 ; P$ $=0.036)$ (Table 1). Significantly fewer nymphs emerged $(4.0 \pm 1.9$; mean \pm $\mathrm{SE}$ ) from eggs laid by female silverleaf whiteflies treated with the low label rate of novaluron $\left(0.47 \mathrm{~mL} \cdot \mathrm{L}^{-1}\right)$ compared to eggs laid by female adult silverleaf whiteflies treated with the high label 
rate of novaluron $\left(0.63 \mathrm{~mL} \cdot \mathrm{L}^{-1}\right)$ and untreated silverleaf whiteflies (Table 1). Although there was not a significant difference in the number of live nymphs between the high label rate of novaluron and the untreated control, there was a substantial numerical difference (Table 1).

Expт. 2. As with Expt. 1, there were no significant differences in the number of live eggs $(F=0.40$; $\mathrm{df}=$ $2,20 ; P=0.68)$ and number of live nymphs $4 \mathrm{~d}$ after female silverleaf whiteflies were placed onto rose-ofchina plants (Table 2). Additionally, there was no significant difference in the number of live eggs laid by female silverleaf whiteflies treated with both label rates of novaluron $(F=2.35 ; \mathrm{df}$ $=2,20 ; P=0.13) 8 \mathrm{~d}$ after female silverleaf whiteflies were placed onto rose-of-china plants; however, the number of eggs that hatched into nymphs was significantly different $(F$ $=4.64 ; \mathrm{df}=2,20 ; P=0.032)$, as the adult female silverleaf whiteflies treated with both rates of novaluron had significantly fewer live nymphs present than untreated silverleaf whiteflies (Table 2).

Although we did not assess the number of dead eggs for Expt. 1, we did for Expt. 2, where the number of dead eggs was significantly different among the treatments $(F=19.39 ; \mathrm{df}=$ $2,20 ; P=0.0002) 8 \mathrm{~d}$ after exposure to novaluron. Female silverleaf whiteflies treated with the high rate of novaluron $\left(0.63 \mathrm{~mL} \cdot \mathrm{L}^{-1}\right)$ had the highest number of dead eggs compared to female silverleaf whiteflies treated with the low rate of novaluron $\left(0.47 \mathrm{~mL} \cdot \mathrm{L}^{-1}\right)$ and untreated female silverleaf whiteflies (Table 2). Both treatment levels had significantly more dead eggs than the untreated silverleaf whiteflies, which had no dead eggs (Table 2).

\section{Discussion}

Insect growth regulators are primarily used on the immature stages of a number of interior plantscape insect pests, including citrus mealybug (Planococcus citri), long-tailed mealybug (Pseudococcus longispinus), and brown soft scale (Coccus hesperi-

Table 1. Mean \pm SE number of live eggs and live nymphs of silverleaf whitefly (Bemisia argentifolii) on transvaal daisy (Gerbera jamesonii) plants 4 and $8 \mathrm{~d}$ after treatment (DAT) with novaluron at both the low and high label-recommended rates, and an untreated control for Expt. 1 .

\begin{tabular}{lccccc}
\hline Treatment & $\mathbf{n}$ & $\begin{array}{c}\text { Rate }^{\mathrm{z}} \\
\left(\mathbf{m L} \cdot \mathrm{L}^{-1}\right)\end{array}$ & DAT $^{\mathrm{y}}$ & $\begin{array}{c}\text { No. live } \\
\text { whitefly eggs } \\
(\text { mean } \pm \mathrm{SE})\end{array}$ & $\begin{array}{c}\text { No. live } \\
\text { whitefly nymphs } \\
(\text { mean } \pm \mathrm{SE})\end{array}$ \\
\hline Novaluron & 7 & 0.47 & 4 & $89.1 \pm 12.7 \mathrm{a}^{\mathrm{x}}$ & $3.5 \pm 1.9 \mathrm{a}$ \\
Novaluron & 7 & 0.63 & 4 & $76.1 \pm 8.6 \mathrm{a}$ & $4.8 \pm 1.3 \mathrm{a}$ \\
Untreated control & 7 & --- & --- & $72.8 \pm 13.4 \mathrm{a}$ & $5.7 \pm 2.4 \mathrm{a}$ \\
Novaluron & 7 & 0.47 & 8 & $96.4 \pm 12.0 \mathrm{a}$ & $4.0 \pm 1.9 \mathrm{~b}$ \\
Novaluron & 7 & 0.63 & 8 & $77.6 \pm 5.8 \mathrm{a}$ & $7.3 \pm 2.8 \mathrm{ab}$ \\
Untreated control & 7 & --- & --- & $61.0 \pm 11.1 \mathrm{a}$ & $17.4 \pm 5.2 \mathrm{a}$
\end{tabular}

${ }^{2}$ Low rate of novaluron $=0.47 \mathrm{~mL} \cdot \mathrm{L}^{-1}(6.0 \mathrm{fl} \mathrm{oz} / 100 \mathrm{gal})$ and high rate of novaluron $=0.63 \mathrm{~mL} \cdot \mathrm{L}^{-1}(8.0 \mathrm{fl}$ $\mathrm{Oz} / 100 \mathrm{gal}$ ).

DAT = days after treatment.

${ }^{x}$ Means within a DAT not followed by a common letter are significantly different $(P=0.05)$ as determined by Fisher's protected least significant difference (LSD) test $P \leq 0.05$. dum). However, studies have shown that when adult female greenhouse whiteflies (Trialeurodesvaporariorum) come into direct contact with sprays or wet residues, they lay non-viable eggs or eggs fail to hatch (Yasui et al., 1985). In our study, based on the number of live nymphs for both experiments, and the number of dead eggs in Expt. 2, it appears that adult female silverleaf whiteflies that were treated with novaluron laid non-viable eggs although not all the eggs were non-viable based on the presence of live nymphs. The fact that not all the eggs laid were non-viable may be that the insect growth regulator did not affect the more mature oocytes.

The reason that fewer nymphs were counted on $\mathrm{d} 4$ for both experiments is that silverleaf whitefly eggs typically hatch in 7 to $10 \mathrm{~d}$, depending on temperature (Mahr et al., 2001). Both experiments were terminated after $8 \mathrm{~d}$, which is within the range of egg hatching for silverleaf whitefly; however, it is possible that this was not enough time to allow all the eggs to hatch. In addition, the novaluron treatments may have exhibited delayed eclosion, resulting in nymphs hatching later than the untreated control.

Insect growth regulators suppress reproduction by blocking endocrine secretion or inhibit chorion ovary formation (Asai et al., 1985). For example, pyriproxyfen is active as an ovicide, larvicide, and has been shown to sterilize female greenhouse whiteflies, with activity highest on young eggs that are 1- to 2-d-old (de Vogue, 1999). This insect growth regulator is a potent suppressor of embryogenesis, as female greenhouse whiteflies treated with pyriproxyfen laid non-viable eggs (Ishaaya and Horowitz, 1995).

Buprofezin, anotherinsect growth

Table 2. Mean \pm SE number of live eggs, dead eggs, and nymphs of silverleaf whitefly (Bemisia argentifolii) on rose-of-china (Hibiscus rosa-sinensis) plants 4 and $8 \mathrm{~d}$ after treatment (DAT) with novaluron at both the low and high label-recommended rates, and an untreated control for Expt. 2.

\begin{tabular}{|c|c|c|c|c|c|c|}
\hline Treatment & $\mathbf{n}$ & $\begin{array}{c}\text { Rate }^{\mathrm{z}} \\
\left(\mathrm{mL} \cdot \mathrm{L}^{-1}\right)\end{array}$ & DAT $^{y}$ & $\begin{array}{c}\text { No. live } \\
\text { whitefly eggs } \\
(\text { mean } \pm \text { SE })\end{array}$ & $\begin{array}{c}\text { No. dead } \\
\text { whitefly eggs } \\
(\text { mean } \pm \text { SE }) \\
\end{array}$ & $\begin{array}{c}\text { No. live } \\
\text { whitefly nymphs } \\
(\text { mean } \pm \mathrm{SE})\end{array}$ \\
\hline Novaluron & 7 & 0.63 & 4 & $56.4 \pm 8.4 \mathrm{a}$ & $0.0 \pm 0.0 \mathrm{a}$ & $0.0 \pm 0.0 \mathrm{a}$ \\
\hline Untreated control & 7 & --- & --- & $39.3 \pm 17.1 \mathrm{a}$ & $0.0 \pm 0.0 \mathrm{a}$ & $0.0 \pm 0.0 \mathrm{a}$ \\
\hline Novaluron & 7 & 0.47 & 8 & $44.6 \pm 15.4 \mathrm{a}$ & $10.4 \pm 3.2 \mathrm{a}$ & $1.7 \pm 1.1 \mathrm{~b}$ \\
\hline
\end{tabular}

${ }^{2}$ Low rate of novaluron $=0.47 \mathrm{~mL} \cdot \mathrm{L}^{-1}(6.0 \mathrm{fl} \mathrm{oz} / 100 \mathrm{gal})$ and high rate of novaluron $=0.63 \mathrm{~mL} \cdot \mathrm{L}^{-1}(8.0 \mathrm{fl} \mathrm{oz} / 100 \mathrm{gal})$.

DAT $=$ days after treatment

${ }^{x}$ Means within a DAT not followed by a common letter are significantly different $(P=0.05)$ as determined by Fisher's protected least significant difference (LSD) test $P \leq 0.05$ 
regulator, has activity on both eggs and adults, with sweet potato whitefly females treated with buprofezin laying eggs that fail to hatch. However, treating adult insects with buprofezin has a greater effect on egg viability than treating eggs directly (Asai et al., 1983). For example, adult sweet potato whiteflies in contact with buprofezintreated tomato (Lycopersicon esculentum) leaves for more than 24 h laid eggs that failed to hatch (Yasui et al., 1987). This indicates that buprofezin enters the insect body and reduces egg viability by affecting the ovaries (Asai et al., 1983; Yasui et al., 1987).

The insect growth regulator diflubenzuron has a mode of activity similar to buprofezin and may also impact whitefly reproduction by disturbing endocuticle deposition and inhibiting normal cuticle formation (Hajjar and Casida, 1978). In fact, both diflubenzuron and novaluron have a similar chemical structure, same mode of activity, and are in the same chemical family, benzoylurea (Thomson, 2001). However, novaluron is relatively new and minimal information is available on how it affects silverleaf whitefly reproduction.

Any differences observed in the number of eggs laid between Expt. 1 and Expt. 2 may have been due to plant type (transvaal daisy vs. rose-of-china) or the age of the whiteflies in the colony. However, insect growth regulators have been shown to reduce egg viability regardless of the age of female whiteflies (Asai et al., 1985). Furthermore, the results are similar across experiments, despite the different plant types used, in that the number of eggs laid by female silverleaf whiteflies, and treated with the low rate of novaluron in Expt. 1 that hatched into nymphs 8 DAT, were significantly less than untreated silverleaf whiteflies (Table 1). Moreover, for Expt. 2, the number of eggs laid by female silverleaf whiteflies, and treated with the low and high rate of novaluron that hatched into nymphs 8 DAT, were significantly and numerically less than silverleaf whiteflies that were untreated (Table 2). In fact, for Expt. 1 (8 DAT) there were $77 \%$ and $58 \%$ fewer nymphs in the low and high rates of novaluron, respectively, relative to the untreated control. Likewise, in Expt. 2 (8 DAT) there were 93\% and $96 \%$ fewer nymphs for the low and high rates of novaluron, relative to the untreated control. Although we did not count the number of dead eggs for Expt. 1, the results from both experiments are similar and indicate that, based on live silverleaf whitefly nymphs, the insect growth regulator negatively affected egg viability.

The fact that insect growth regulators indirectly affect the adult stages of certain insect species is important in regard to pest control, as this means that another developmental life stage is negatively affected. Suppressing reproduction by treating adult female silverleaf whiteflies is an important long-term pest management strategy. (Yasui et al., 1987). Fewer eggs will hatch into nymphs, resulting in populations taking longer to build up to damaging levels; thus providing greenhouse producers more time to deal with silverleaf whitefly infestations.

This study is significant to greenhouse producers because the results demonstrate that the insect growth regulator novaluron, which is active on the nymphal stage of silverleaf whiteflies, also negatively affects female silverleaf whitefly reproduction by reducing egg viability. This can decrease the number of whiteflies that occur during a cropping cycle. As a result, fewer insecticide applications may be needed, which may reduce insecticide and labor costs, and avoid worker exposure to insecticide residues.

\section{Literature cited}

Asai, T., O. Kajihara, M. Fukada, and S. Maekawa. 1985. Studies on the mode of action of buprofezin II. Effects on reproduction of the brown planthopper, Nilaparvata lugens Stal (Homoptera: Delphacidae). Appl. Entomol. Zoolog. 20:111-117.

Asai, T., M. Fukuda, S. Maekawa, K. Ikeda, and H. Kanno. 1983. Studies on the mode of action of buprofezin. I. Nymphcidal and ovicidal activities on the brown rice planthopper, Nilaparvata lugens Stal. (Homoptera: Delphacidae). Appl. Entomol. Zoolog. 18:550-552.

de Vogue, E. 1999. Admiral, a new insecticide for the control of aleyrodid on tomatoes. Proc. 5th Intl. Conf. Pests and Agr., Montpellier, France. Part I:185-190.

Dreistadt, S.H. 2001. Integrated pest management for floriculture and nurseries. Univ. of California Statewide Integrated Pest Mgt. Project, Univ. of California Div. of Agr. and Natural Resources Publ. 3402.

Hajjar, N.P. and J.E. Casida. 1978. Insecticidal benzoyphenylurea: Structure-activity relationships as chitin synthesis inhibitors. Science 200:1499-1500.
Ishaaya, I., S. Yablonski, Z. Mendelson, Y. Mansour, and A.R. Horowitz. 1996. Novaluron (MCW-275), a novel benzoylphenyl urea, suppressing developing stages of lepidopteran, whitefly and leafminer pests. Proc. Intl. Conf: Pests and Dis., vol. 3:1013-1020. Brighton Crop Protection Conf., Brighton, U.K.

Ishaaya, I. and A.R. Horowitz. 1995. Pyriproxyfen, a novel insect growth regulator for controlling whiteflies: Mechanisms and resistance management. Pesticide Sci. 43:227-232.

Lindquist, R.K. 1998. Integrated insect and mite management on poinsettias. Ohio Florists' Bul. 825:19-22.

Lindquist, R.K. 1990. Insect control, p. 46-54. In: Tips on growing poinsettias, 2 nd ed. Ohio Coop. Ext. Serv., Ohio State Univ., Columbus.

Mahr, S.E.R., R.A. Cloyd, D.L. Mahr, and C.S. Sadof. 2001. Biological control of insects and other pests of greenhouse crops. North Central Reg. Publ. 581. Univ. of Wisconsin Coop. Ext, Madison.

Medina, P., G. Smagghe, F. Budia, L. Tirry, and E. Vinuela. 2003. Toxicity and absorption of azadirachtin, diflubenzuron, pyriproxyfen, and tebufenozide after topical application in predatory larvae of Chrysoperla carnea (Neuroptera: Chrysopidae). Environ. Entomol. 32:196-203.

Nassar, S.G., G.B. Staal, and N.I. Armanious. 1972. Effects and control potential of insect growth regulators with juvenile hormone activity on greenbug. J. Econ. Entomol. $66: 847-850$.

Olkowski, W., S. Daar, and H. Olkowski. 1991. Common sense pest control. Taunton Press, Newton, Conn.

Robb, K.L. 1989. Analysis of Frankliniella occidentalis (Pergande) as a pest of floricultural crops in California greenhouses. PhD Diss., Univ. of California, Riverside. Diss. Abstr. No. 9002637.

SAS Institute, Inc. 2002. SAS Systems for Windows, version 8.0. SAS Inst., Cary, N.C.

Thomson, W.T. 2001. Agricultural chemicals book I: Insecticides. Thomson Publ., Fresno, Calif.

Ware, G.W. 2000. The pesticide book. Freeman, San Francisco.

Yasui, M., M. Fukada, and S. Maekawa. 1987. Effects of buprofezin on reproduction of the greenhouse whitefly, Trialeurodes vaporariorum (Westwood) (Homoptera: Aleyrodidae). Appl. Entomol. Zoolog. 22:266-271.

Yasui, M., M. Fukada, and S. Maekawa. 1985. Effects of buprofezin on different developmental stages of the greenhouse whitefly, Trialeurodes vaporariorum (Westwood) (Homoptera: Aleyrodidae). Appl. Entomol. Zoolog. 20:340-347. 